\title{
Availability of Life Support Equipment and its Utilization by Ambulance Drivers
}

\author{
Rija Acharya, ${ }^{1}$ Angur Badhu, ${ }^{2}$ Tara Shah, ${ }^{2}$ Sharmila Shrestha ${ }^{2}$ \\ 1'Department of Nursing, Nepal Medical College Teaching Hospital, Kathmandu, 2Department of \\ Community Health Nursing, B.P. Koirala Institute of Health Science, Dharan, Nepal.
}

\begin{abstract}
Background: An effective ambulance is a vital requirement for providing an emergency medical service. Wellequipped ambulances with trained paramedics can save many lives during the golden hours of trauma care. The objective was to document the availability and utilization of basic life support equipment in the ambulances and to assess knowledge on first aid among the drivers.

Methods: Descriptive design was used. Total of 109 ambulances linked to B.P. Koirala Institute of Health Sciences were enrolled using purposive sampling method. Self- constructed observation checklist and semi structured interview schedule was used for data collection.

Results: More than half of the respondents had less than five years of experience and were not trained in first aid. About two-third of the respondents had adequate knowledge on first aid. About $90 \%$ of the ambulance had oxygen cylinder and adult oxygen mask which was 'usually' used equipment. More than half of ambulance had equipment less than $23 \%$ as compared to that of national guidelines. There was significant association of knowledge with the experience $(p=0.004)$ and training $(p=0.001)$. Availability of equipment was associated with training received $(p$ $=0.007)$, organization $(\mathrm{p}=0.032)$ and district $(\mathrm{p}=0.023)$ in which the ambulance is registered.

Conclusions: The study concludes that maximum ambulance linked to BPKIHS, Nepal did not have even one fourth of the equipment for basic life support. Equipment usually used was oxygen cylinder and oxygen mask. Majority of driver had adequate knowledge on first aid and it was associated with training and experience.

Keywords: Availability; knowledge; utilization.
\end{abstract}

\section{INTRODUCTION}

World Health Organization regards emergency medical systems(EMS) as an integral part of any effective and functional health care system. EMS consist of different component like pre-hospital care, equipment and communication, transportation of the patient to the hospital and health facilities. ${ }^{1}$ An effective ambulance is a vital requirement for providing an emergency medical service. Well-equipped ambulances with trained paramedics can save many lives during golden hours of trauma care. In Nepal, a large number of people die annually due to lack of access to well-equipped health care services for immediate treatment of sudden fatal illness, accidents or complication in child birth. Majority of the death could be prevented with a professional functioning transportation system. ${ }^{2}$ For an effective ambulance service system to be developed, the existing facilities need to be studied. The objective was to document availability and utilization of basic life support equipment in ambulances and to assess knowledge on first aid among the ambulance driver.

\section{METHODS}

Descriptive design was used for the study. The study was conducted within the premises of B.P. Koirala Institute of Health Science. As it is a tertiary level referral center hospital, ambulances from most of the districts of eastern region are linked to this center. Purposive sampling method was used and a total of 109 ambulance linked to BPKIHS were enrolled in the study.

Self-constructed interview schedule, observation 
checklist and rating scale was used to collect data. Interview schedule consisted of questions related to knowledge on first aid. Observation checklist consisted of list of equipment to be available for basic life support. It was made based on the National guideline for ambulance for Basic Life support, Category B(National Ambulance Service Operational Policy, Nepal). Rating scale consisted of items to document utilization of available equipment by ambulance driver. Utilization of equipment was documented on the basis of verbal response provided by the participants. Descriptive statistics (frequency, percentage, mean, standard deviation) was used to describe the demographic characteristics of participant. Knowledge of the participants on first aid and availability of equipment was assessed by calculating percentage score. Regarding knowledge on first aid, there were total 18 knowledge related question for which score 1 was given for correct answer and 0 for wrong answer.

The score of all respondent was converted into percentage score and mean percentage was calculated at $95 \%$ Confidence Interval $(\mathrm{Cl})$ and lower bound mean score was taken as a reference value. Those respondent acquiring score mean percentage score were considered having "adequate knowledge" and those obtaining score mean percentage score were considered having "inadequate" knowledge. Association of percentage score of knowledge was seen with selected variable using Independent Sample t- test and ANOVA. P value $\leq 0.05$ was considered as statistically significant. There were total 22 items to be present in the ambulance for basic life support. Score 1 was given for presence of the equipment and 0 for absence. The obtained score was calculated in percentage score and association was calculated with selected variable. For categorization of availability of equipment, the score of all respondent was converted into percentage score and mean percentage was calculated at $95 \%$ Confidence Interval $(\mathrm{Cl})$ and lower bound mean score was taken as a reference value. Availability was categorized as having equipment above mean score and below mean score. Ethical permission was obtained from Institutional Review Committee of BPKIHS.

\section{RESULTS}

Ages of respondents were between 19-58 years with mean age $34.1 \pm 8.3$. Maximum (44.0\%) were in the age group $25-35$ years. Two third $(66.1 \%)$ of the respondents had received secondary level of education. About half (48.6\%) of the ambulances were from Sunsari. Threefourth $(75.2 \%)$ of the ambulance were run by the private organization. More than half $(56.9 \%)$ of the respondents had not received any training on first aid. (Table 1)

\begin{tabular}{|c|c|c|c|}
\hline Characteristics & Categories & Frequency & Percent \\
\hline \multirow[t]{5}{*}{ Age in years } & Less than 25 & 17 & 15.6 \\
\hline & $25-35$ & 48 & 44.0 \\
\hline & $35-45$ & 35 & 32.1 \\
\hline & $>45$ & 9 & 8.2 \\
\hline & \multicolumn{3}{|c|}{ Mean S.D $=34.18 .3$, Range $=19-58$} \\
\hline \multirow[t]{4}{*}{ Education } & Literate Only & 5 & 4.6 \\
\hline & Primary & 20 & 18.3 \\
\hline & Secondary & 72 & 66.1 \\
\hline & $\begin{array}{l}\text { Higher } \\
\text { Secondary } \\
\text { and above }\end{array}$ & 12 & 11.0 \\
\hline \multirow[t]{5}{*}{ District } & Sunsari & 53 & 48.6 \\
\hline & Morang & 19 & 17.4 \\
\hline & Jhapa & 14 & 12.8 \\
\hline & Saptari & 7 & 6.4 \\
\hline & Other & 16 & 14.6 \\
\hline \multirow{3}{*}{$\begin{array}{l}\text { Type of } \\
\text { organization }\end{array}$} & Governmental & 11 & 10.1 \\
\hline & Private & 82 & 75.2 \\
\hline & $\begin{array}{l}\text { Non- } \\
\text { governmental }\end{array}$ & 16 & 14.7 \\
\hline
\end{tabular}

Majority of the respondents had provided correct answers regarding definition of first aid, first aid when patient is not breathing, first aid in cut-injury, necessity of humidifier in oxygen cylinder (Table 2).

\section{Table 2. Knowledge on first aid and equipment}

\section{$(n=109)$.}

\section{Category}

Definition of First aid

Prioritization of first aid concept

Assessment of unconscious patient

First aid when patient is not breathing

Position during difficulty in breathing (in non-trauma

case)

Position when obstruction of mouth by secretion

First aid for fracture of legs

Basics of splinting

85 78.0

First aid in cut- injury 100 


\begin{tabular}{|lcr|}
$\begin{array}{l}\text { Transfer of patient with neck } \\
\text { injury }\end{array}$ & 62 & 56.9 \\
$\begin{array}{l}\text { Rate of oxygen through face } \\
\text { mask }\end{array}$ & 65 & 59.6 \\
\hline $\begin{array}{l}\text { Rate of oxygen through nasal } \\
\text { catheter }\end{array}$ & 82 & 75.2 \\
\hline $\begin{array}{l}\text { Do not open patients mouth } \\
\text { during seizure }\end{array}$ & 46 & 42.2 \\
\hline $\begin{array}{l}\text { Do not hold the person still } \\
\text { during seizure }\end{array}$ & 30 & 27.5 \\
\hline $\begin{array}{l}\text { Necessity of humidifier } \\
\text { Function of humidifier }\end{array}$ & 106 & 97.2 \\
\hline Normal Pulse Rate & 31 & 28.4 \\
\hline $\begin{array}{l}\text { Oxygen administration during } \\
\text { cyanosis }\end{array}$ & 18 & 16.5 \\
\hline
\end{tabular}

Majority $(64.2 \%)$ of the driver had adequate knowledge on first aid. More than half (53.2\%) of ambulance had equipment less than mean score $(23.2 \%)$ as compared to that of required for basic life support. The maximum score was $45.4 \%$ while lowest score was $4.5 \%$. It shows that majority of ambulance in Nepal did not have even one fourth of the equipment for basic life support as mentioned in national guideline. (Table 3)

\section{Table 3. Score on Knowledge on First Aid and}

availability of equipment $(n=109)$.

\begin{tabular}{|c|c|c|c|}
\hline Category & Characteristic & Frequency & Percent \\
\hline \multirow{3}{*}{$\begin{array}{l}\text { Knowledge } \\
\text { on first aid }\end{array}$} & Inadequate & 39 & 35.8 \\
\hline & Adequate & 70 & 64.2 \\
\hline & \multicolumn{3}{|c|}{$\begin{array}{c}\text { Mean } \pm S . D=55.5 \pm 13.4, \text { Maximum }= \\
83.3 \%, \text { Minimum }=22.2 \%\end{array}$} \\
\hline \multirow{3}{*}{$\begin{array}{l}\text { Availability } \\
\text { of equipment }\end{array}$} & $<23 \%$ & 58 & 53.2 \\
\hline & $\geq 23$ & 51 & 46.8 \\
\hline & \multicolumn{3}{|c|}{$\begin{array}{c}\text { Mean } \pm S . D=23.2 \pm 8.9, \\
\text { Maximum }=45.4 \%, \text { Minimum }=4.5 \%,\end{array}$} \\
\hline
\end{tabular}

Table 4. Availability and Utilization of Available Equipment in Ambulance.

\begin{tabular}{|lrrrrrrrr}
\hline Equipment & Available & Percent & Always & Usually & Sometimes & Occasionally & Never \\
\hline First aid box & 54 & 49.5 & $1(1.9 \%)$ & $1(1.9 \%)$ & $8(14.8 \%)$ & $24(44.4 \%)$ & $20(37 \%)$ \\
\hline Oxygen Cylinder & 108 & 99.1 & $4(3.7 \%)$ & $42(38.8 \%)$ & $44(40.7 \%)$ & $18(16.6 \%)$ & - \\
\hline Adult oxygen mask & 101 & 92.7 & $1(0.9 \%)$ & $41(40.6 \%)$ & $42(41.6 \%)$ & $17(16.8 \%)$ & - \\
\hline Pediatric oxygen mask & 63 & 57.8 & - & $28(44.4 \%$ & $30(47.6 \%)$ & $5(7.9 \%)$ & - \\
\hline Nasal Catheter & 51 & 46.7 & - & $12(23.5 \%)$ & $35(68.6 \%)$ & $4(7.8 \%)$ & - \\
\hline I/V cannula & 1 & 0.9 & - & - & - & - & $1(100 \%)$ \\
\hline I/V infusion set & 1 & 0.9 & - & - & - & - & - \\
\hline I/V stand & 93 & 85.3 & - & $4(4.3 \%)$ & $32(34.4 \%)$ & $54(58.1 \%)$ & $3(3.2 \%)$ \\
\hline Stretcher cum bed & 73 & 67.0 & - & $3(4.1 \%)$ & $3(4.1 \%)$ & $42(57.5 \%)$ & $25(34.2 \%)$ \\
\hline Hand washing facility & 15 & 13.8 & - & $1(6.7 \%)$ & $2(13.3 \%)$ & $10(66.7 \%)$ & $2(13.3 \%)$ \\
\hline Adult AMBU bag & 41 & 37.6 & - & $1(2.4 \%)$ & $11(26.8 \%)$ & $26(63.4 \%)$ & $3(7.3 \%)$ \\
\hline Pediatric AMBU bag & 12 & 11.0 & - & - & $2(16.7 \%)$ & $9(75 \%)$ & $1(8.3 \%)$ \\
\hline
\end{tabular}

Table 5. Association of Knowledge and Availability of Equipment with Selected Variable (n=109).

\begin{tabular}{|c|c|c|c|c|c|c|}
\hline \multirow[t]{2}{*}{ Variable } & Category & Number & Knowledge & \multirow[t]{2}{*}{$P$ value } & Availability of equipment & \multirow[t]{2}{*}{ P Value } \\
\hline & & & MeanS.D. & & MeanS.D. & \\
\hline \multirow{4}{*}{ Age* } & $<25$ years & 17 & 48.615 .0 & \multirow{4}{*}{0.138} & 24.19 .2 & \multirow{4}{*}{0.151} \\
\hline & 25-35 years & 48 & 56.212 .8 & & 28.410 .5 & \\
\hline & 35-45years & 35 & 57.713 .6 & & 28.88 .0 & \\
\hline & $>45$ years & 9 & 56.911 .3 & & 21.6 .4 & \\
\hline
\end{tabular}




\begin{tabular}{|c|c|c|c|c|c|c|}
\hline \multirow{3}{*}{ Education* } & $<$ Secondary & 25 & 57.111 .5 & \multirow{3}{*}{0.262} & 27.410 .0 & \multirow{3}{*}{0.997} \\
\hline & Secondary & 72 & 54.213 .4 & & 27.29 .9 & \\
\hline & >Secondary & 12 & 60.617 .4 & & 27.59 .4 & \\
\hline \multirow{3}{*}{ Organization* } & Governmental & 11 & 49.413 .4 & \multirow{3}{*}{0.119} & 207.7 & \\
\hline & Private & 82 & 55.813 .1 & & 28.210 .0 & \\
\hline & Non-governmental & 16 & 60.413 .1 & & 27.88 .3 & 0.032 \\
\hline \multirow{2}{*}{$\begin{array}{l}\text { Training } \\
\text { received }^{* *}\end{array}$} & Yes & 47 & 61.711 .5 & \multirow{2}{*}{0.001} & 30.28 .9 & \\
\hline & No & 62 & 50.913 .2 & & 25.29 .9 & 0.007 \\
\hline \multirow{2}{*}{ Experience** } & $<5 y e a r$ & 64 & 52.413 .9 & \multirow{2}{*}{0.004} & 25.910 .4 & 0.076 \\
\hline & > 5 year & 45 & 60.111 .7 & & 29.38 .6 & \multirow{3}{*}{0.023} \\
\hline \multirow{2}{*}{ District $^{* *}$} & Sunsari & 53 & 55.413 .0 & \multirow{2}{*}{0.908} & 29.59 .5 & \\
\hline & Other & 56 & 55.714 .0 & & 25.29 .7 & \\
\hline * ANNOVA & \multicolumn{6}{|c|}{${ }^{* *}$ Independent sample $t$ test } \\
\hline
\end{tabular}

Most (90\%) of the ambulances had oxygen cylinder and adult oxygen mask. Provision of I/V stand/hook was present in $85.3 \%$ of ambulances $(28.4 \%$ had I/V stand and $56.9 \%$ had presence of hook). More than half of the ambulances had pediatric oxygen mask and stretcher cum bed (Table 4). Other equipment to be present in the basic life support ambulance like suction, machine, cervical collar, fracture splint, I/V fluids, Stethoscope, B.P apparatus, spine support, airway, patient restraint strap, torchlight were also observed but none of the ambulance had these equipment.

Equipment "usually" used were oxygen cylinder in more than one third of the ambulance and adult oxygen mask in $40.6 \%$ of ambulance while nasal catheter was "sometimes" used in more than two-third of ambulance. Similarly, equipment that were "occasionally" used were first-aid box I/V stand (58.1\%), stretcher cum bed (57.5\%), handwashing facility (66.7\%) and adult AMBU bag (63.4\%) (Table 4).

There was significant association of knowledge with the experience $(p=0.004)$ and training $(p=0.001)$. The mean score was higher in those who had experience $>$ 5 year and had received training. There was significant association of availability with training $(p=0.007)$, organization $(p=0.032)$ and district $(p=0.023)$ in which the ambulance is registered. Mean score was higher in those who had received training, ambulance run by private organization and those registered in Sunsari district. (Table 5)

\section{DISCUSSION}

In this study, equipment available in the ambulances were assessed according to the guidelines provided in the National Ambulance Operational Policy. The findings showed that more than half $(58.7 \%)$ of the respondents had less than 5 years of experience and similar percentage had not received any training on first aid. This does not meet the national guideline on ambulance provided by Nepal. It states that a person must have at least 5 year of driving experience to be an ambulance driver and should be trained in first aid. ${ }^{3}$

The study showed that majority (62.4\%) of the respondents had adequate knowledge on first aid. There was significant association of knowledge with the experience and training. This shows that providing training to the ambulance driver in first aid increases their knowledge and helps in providing appropriate care to the patients. This finding was supported by the findings of study conducted in Vienna area among bystanders where they found a clear relationship between the level of first aid training and the quality of first aid measures provided. ${ }^{4}$

Majority $(82.6 \%)$ of the respondents mentioned that first aid means the first treatment given at accident site and one third (34.9\%) correctly prioritized airway management in first aid concept. The study conducted on Nigeria among commercial inner city driver showed that $34.6 \%$ of the driver responded first aid as what 
is done for the patient at the accident site and $59.9 \%$ correctly prioritized airway management in first aid concept. $^{5}$

About $20.2 \%$ of ambulance had only about one-fourth of equipment required for basic life support as mentioned in National guideline, Nepal. None of the ambulance had greater than $50 \%$ of the equipment. This is far less than the finding of the similar study conducted in Iran where it was found that road ambulances have an average of about $51 \%$ of equipment as mentioned by $\mathrm{MOH}$ of Iran. ${ }^{6}$

In this study, equipment 'usually' used in the ambulance were oxygen cylinder in $38.5 \%$ and adult oxygen mask in $40.6 \%$ which is supported by the study conducted in Klang Valley of Malaysia which showed that oxygen delivery devices were used in $45.8 \%$ of the ambulance. ${ }^{7}$

\section{CONCLUSIONS}

The study concludes that majority of ambulance linked to BPKIHS, did not have even one fourth of the equipment for basic life support. Commonly available equipment were oxygen cylinder, oxygen mask, first aid box, intravenous fluid stand and stretcher cum bed. The equipment usually used was oxygen cylinder and oxygen mask. Majority of ambulance drivers had adequate knowledge on first aid and was significantly associated with training and experience of driver. Availability of equipment was significantly associated with training of driver, type of organization that runs the ambulance and district in which ambulance is registered.

\section{REFERENCES}

1. Al-Shaqsi S. Models of international emergency Medical service system. Oman Med J. 2010;25(4): 320-3 $\underline{\text { Link }}$

2. Paudel SR. Study of Ambulance service in Nepal Including Lesson Learned and Recommendation. Nepal Safe Motherhood Project. 2002;43 p. Link
3. Ministry of Health and Population, Nepal. Nepal Ambulance Service Operational Policy, 2003. Ministry of Health and Population. 2014. 9 p.Link

4. Mauritz W, Pelinka LE, Kaff A, Segall B, Fridrich P. First aid measures by bystanders at the place of accident. A prospective, epidemiologic study in the Vienna Area. Wien Klin Wochenschr. 2003; 115(1920): 698-704. Link

5. Olugbenga-Bello AI, Sunday OK, Nicks BA, Olawale OA, Adefisoye AO. First aid knowledge and application among commercial inter-City Drivers in Nigeria. Afr J Emerg Med. 2012; 2(3): 108-13. Link

6. Vatankhah S, Kazamneghad E, Pourshaikhian M. A comparative study of road Ambulances equipment based on the National Standards in Guilan Province. Int J Health Syst Disaster Manage. 2013; 1: 2-6.Link

7. Razzak JA, Kellermann AL. Emergency medical care in developing countries: is it worthwhile? Bull World Health Organ. 2002;80 (11) :900-5 Link 